\title{
The mineralogy and chemistry of the German and Portuguese tiles used to face a historic building in the Amazon region and their natural susceptibility to tropical weathering
}

\author{
Marcondes L. da COSTA ${ }^{1 *}$, Thais A.B.C. SANJAD ${ }^{2, *}$, Rosildo S. PAIVA ${ }^{3}$
}

\begin{abstract}
During the 19th century, the most prominent buildings of the city of Belém were faced entirely with tiles manufactured in Portugal and Germany, which now exhibit distinct degrees of degradation. The Pinho mansion is one of the most important of these buildings and was selected for the investigation of the action of the tropical Amazonian climate on the degradation of the tiles. To achieve this objective, the tiles were mapped for organic and inorganic degradation, and samples were collected for analysis. The minerals were determined by XRD, the chemical composition by classical wet methods and SEM/EDS, and the microorganisms under the microscope. The results show that the German and Portuguese tiles are quite different in their composition. While both ceramic bodies are composed of $\mathrm{SiO}_{2}$ and $\mathrm{Al}_{2} \mathrm{O}_{3}, \mathrm{CaO}$ was found only in the Portuguese tile. The low $\mathrm{Na}_{2} \mathrm{O}$ and $\mathrm{K}_{2} \mathrm{O}$ contents indicate the addition of materials to reduce the fusion temperature. $\mathrm{SiO}_{2}$ and $\mathrm{PbO}$ are the main constituents of the glaze, with $\mathrm{CoO}$ and $\mathrm{FeO}$ being added as pigment. The ceramic body of the German tiles is constituted of quartz, mullite, and cristobalite, in contrast with the Portuguese tiles, which are made of quartz, gehlenite, diopside, calcite, and feldspars. The glazes are XRD-amorphous. The chemical and mineralogical differences between the German and Portuguese tiles indicate that they were produced from different raw materials under distinct thermal processes. The most prominent weathering-related modifications are the thin layers (German tiles), oxidation stains, dark stains, the detachment of the tile (Portuguese tiles), loss of the glaze and powdering of the ceramic body (Portuguese tiles) through the establishment of Cyanophyta and Bacillariophyta.. The distinct degradation patterns of the tiles exposed to the tropical Amazon climate are a consequence of their distinct mineralogy and chemistry.
\end{abstract}

KEYWORDS: German and Portuguese tiles, degradation, tropical weathering, Amazon region

\section{Mineralogia e química de azulejos Alemães e Portugueses de prédios históricos na região Amazônica e sua susceptibilidade natural à degradação tropical (intemperismo)}

\begin{abstract}
RESUMO
As proeminentes edificaçóes da cidade de Belém foram revestidas durante o século 19 com azulejos produzidos em Portugal e Alemanha que já apresentam distintos graus de degradação. O Palacete Pinho é uma das mais importantes destas edificações e foi selecionado para se investigar a ação do clima tropical amazônico sobre a degradação destes azulejos. Para atingir estes objetivos mapearam-se os azulejos desta edificação visando identificar as modificaçôes de origem orgânica e inorgânica e coletas de amostras para análises. Os minerais foram determinados por DRX, a composição química por métodos clássicos úmidos e MEV/SED e os micro-organismos por microscopia. Os resultados obtidos mostram que os azulejos Portugueses e Alemães são distintos entre si. Enquanto o biscoito é composto de $\mathrm{SiO}_{2}$ e $\mathrm{Al}_{2} \mathrm{O}_{3}, \mathrm{CaO}$ foi encontrado apenas nos Portugueses. Os baixos conteúdos de $\mathrm{Na}_{2} \mathrm{O}$ e $\mathrm{K}_{2} \mathrm{O}$ indicam adição de materiais para reduçắo da temperatura de fusão. $\mathrm{SiO}_{2}$ e $\mathrm{PbO}$ compóem o vidrado, já $\mathrm{CoO}$ e FeO foram adicionados como pigmentos. O biscoito dos azulejos Alemáes é constituído de quartzo, mullita e cristobalita, ao contrário do Português com quartzo, gehlenita, diopsídio, calcita e feldspatos. Os vidrados são amorfos ao DRX. As diferenças químicas e mineralógicas entre os azulejos Portugueses e Alemães indicam que foram produzidos por matéria prima distinta, bem como processo termal. As alteraçóes relacionadas com o intemperismo são as finas camadas de detritos (nos Alemães), manchas de oxidação, manchas escuras, descolamento do azulejo (no Português); perda de vidrado e biscoito tornando-se pulverulento como consequência do estabelecimento de Cyanophyta e bacillariophyta (Português). As distintas feiçôes de degradação dos azulejos refletem as suas diferenças mineralógicas e químicas expostas ao clima tropical Amazônico.

PALAVRAS-CHAVE: azulejos Alemães e Portugueses, degradação, intemperismo tropical, região amazônica.

1 Instituto de Geociências, Universidade Federal do Pará, 1 Augusto Corrêa Street, 66075-110, Belém, Pará, Brazil -e-mail: mlc@ufpa.br; *: Corresponding author.

2 Instituto Tecnológico, Universidade Federal do Pará, 1 Augusto Corrêa Street, 66075-110, Belém, Pará, Brazil -e-mail: thais@ufpa.br;

${ }^{3}$ Instituto de Ciências Biológicas, Universidade Federal do Pará, 1 Augusto Corrêa Street, Postal Code 66075-110, Belém, Pará, Brazil -e-mail: rpaiva@ufpa.br
\end{abstract}




\section{INTRODUCTION}

Belém, the capital of the Brazilian state of Pará, was founded on January 12th, 1616, by Francisco Caldeira Castello Branco, on the site of the Presépio military fort, which is located strategically on the margin of Guajará Bay (Figure 1) in the eastern Amazon region. During the 19th century, Belém was an important commercial center, due the Rubber Boom, with a major international port. At this time, many manufactured products, especially building materials, were imported into the city from Europe. European tiles were imported mainly during the 19th and early 20th centuries, and were incorporated into the construction of many prominent buildings, such as the Pinho mansion (Pinho palace). While local buildings were probably faced with tiles as early as the 17 th century, the oldest surviving example - the Portuguese tiles facing the Santo Antônio College, which was originally a convent - dates from the 18th century.

In the 19th century, prominent buildings in Belém, like the rest of Brazil, were faced entirely with tiles, a practice which was most prominent during the Rubber Boom (Alcântara 1980). Most of the tiles were manufactured in Portugal, but some came from other countries, especially France, England and Germany. The German tiles were mainly produced by the Villeroy \& Boch factory where production continues to the present day.

While tiles used for external facing are typically made of materials that are distinctly resistant to weathering, the extremely hot and humid conditions of equatorial latitudes like the Amazon region form a particularly challenging environment, especially for materials that have been exposed for more than 100 years, as in the case of buildings constructed in the 19th century in the city Belém. The Pinho mansion is a typical example, and its tiles have been modified distinctively

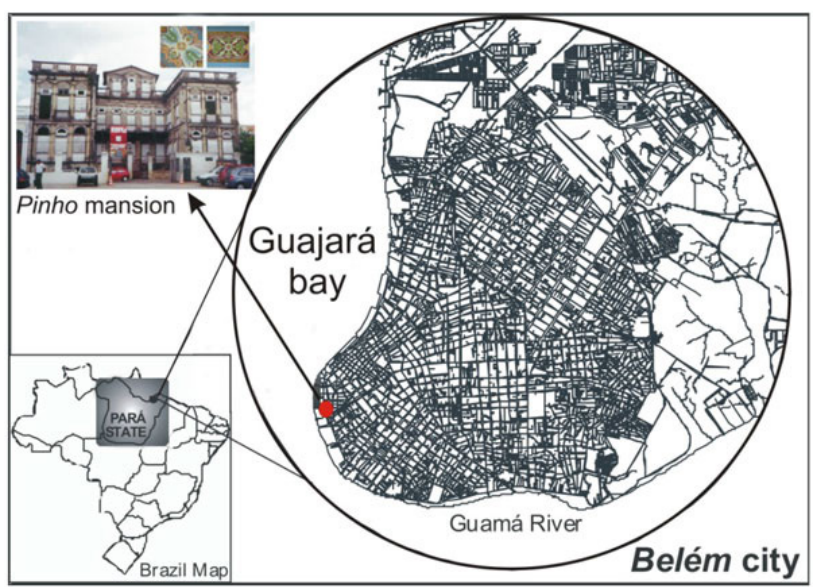

Figure 1 - A map of the city of Belém showing the location of the Pinho mansion. Geographical Coordinates of the Pinho mansion: 1027'39.85" S/48 $30^{\prime} 17.48^{\prime \prime}$ W. These photographs are shown in color in the electronic version. by the tropical conditions. Some of the tiles have been modified considerably, with a loss of glazing, functionality, and esthetic quality.

The aims of the present study are to characterize the building materials and their modifications in order to understand how the tropical Amazon weathering contributes to the modification and degradation of the tiles facing the walls of the centennial buildings of the city of Belém, such as the Pinho mansion, one of the most important tile-faced buildings in Belém in terms of architectural complexity, decoration pattern and history, but presenting extensive natural alterations.

The Pinho mansion is located in the Old City ("Cidade Velha") district, and was constructed in 1897 by Camilo de Amorim as the residence of the trader Antônio José de Pinho. The façades of the building were originally covered with two types of tiles, German material manufactured by Villeroy \& Boch (Metallach) and Portuguese tiles from the city of Porto. The building had been left abandoned for a number of years, and during this period, it lost more than half of its tiles, which were either stolen or destroyed by weathering.

The city of Belém is located within Köppen's Af (tropical wet and hot) climatic domain. Mean annual temperature is approximately $26^{\circ} \mathrm{C}$ (minimum $20^{\circ} \mathrm{C}$ and maximum 33 ${ }^{\circ} \mathrm{C}$ ), and mean annual precipitation is $2600 \mathrm{~mm}$, with relative humidity of around to 88 to $98 \%$. Two climate seasons can be observed: a rainy season, from December to May, and a drier season during the remaining months of the year. The original habitat is equatorial rainforest, with alluvial forests and mangroves. Climatic data collected over the past hundred years indicate that local conditions have varied very little during this time (Sanjad 2007).

\section{MATERIALS AND METHODS}

\section{Sampling}

Before sampling, the façade of the Pinho building was mapped in order to identify the distribution of distinct types of tiles and the products of their degradation. All mapped tiles presented some form of alteration. After tile mapping, two samples of the German tiles (denominated PPA and PPA-C) and one of the Portuguese tiles (denominated PPP) were selected as being most representative of the different kinds of modifications indentified on the façade. We obtained permission for the removal of only these three complete tiles, which were taken from existing lacunae in order to avoid creating additional gaps in the façade. These tiles were complemented with partial samples taken from other tiles representing distinct patterns of modification, with five samples being obtained for each type of alteration. 


\section{Chemical Analysis}

The total chemical composition of the ceramic portion of the tiles was determined by gravimetry for $\mathrm{SiO}_{2}$; titrimetry for $\mathrm{Al}_{2} \mathrm{O}_{3}$; spectrophotometry for $\mathrm{Fe}_{2} \mathrm{O}_{3}$ and $\mathrm{TiO}_{2}$ (colorimetric method); and flame atomic absorption spectrometry (3320 AA, Perkin Elmer, Germany) for $\mathrm{Na}_{2} \mathrm{O}, \mathrm{K}_{2} \mathrm{O}, \mathrm{CaO}$ and $\mathrm{MgO}$. Chemical analysis of the glaze was limited to semi-quantitative scanning electron microscopy (SEM) coupled to an Energy Dispersive X-Ray Spectroscopy (SEM/EDS) of the polished section of the tiles using a ZEISS model LEO $1430 \mathrm{VP}$ (Cambridge, England).

\section{Mineralogical analysis}

The mineralogy of the samples was identified by X-ray diffraction analysis (XRD), using the powder method in a Philips PW 3710 diffractometer with a Philips PW 3020 goniometer (Netherland). The XRD analyses were run from $5^{\circ}$ to $65^{\circ} 2 \theta$. Identification by XRD was supported by the preceding SEM/EDS analysis.

\section{Measurement of tile morphology, density and water absorption}

The thickness of the glaze and ceramics was measured with an optical microscope (Axiolab-Pol, Carl Zeiss), and density was determined by a Hubbard picnometer, according to the Italian procedure (Normal 4/80 methodology). Total water absorption was measured using the Brazilian NBR 12766 protocol, in order to determine the accessible porosity of the ceramic portion of the tile. Agents of biological degradation were also identified under an optical microscope.

\section{RESULTS}

\section{Tile morphology}

The German tiles were square in shape (Figure 2) and painted with motifs based on either a two-fold (sample
PPA-C) or four-fold symmetry axis (PPA). The two-fold axis tiles are arranged around the four-fold axis tiles on the façade of the building. Both styles were produced at the turn of the 19th century, and represent the soft-relief decorative technique with colored decorations applied directly to the white ceramic base.

The Portuguese tiles are rectangular with chamfered edges and decorated with a marbling effect, applied directly to the ceramic portion of the tile, which is covered by a colorless glaze. The German tiles were used to face the upper part of the façade of the Pinho mansion, while the Portuguese tiles were used in the lower part, at ground level.

\section{Chemistry of the ceramics and glaze}

The ceramic portion of the German tiles (samples PPA and PPA-C) is composed mainly of $\mathrm{SiO}_{2}$ and $\mathrm{Al}_{2} \mathrm{O}_{3}$. In addition to these two oxides, the Portuguese tile (sample PPP) contains a high proportion of $\mathrm{CaO}$ (Table 1). The low $\mathrm{Fe}_{2} \mathrm{O}_{3}$ content

Table 1 - The chemical composition (weight \%) of the ceramic body of the tiles from the Pinho mansion. PPA and PPA-C: Sample code for the German tiles; PPP: Sample code for the Portuguese tile. LOI: Lost of Ignition.

\begin{tabular}{cccc}
\hline Samples & PPA & PPA-C & PPP \\
\hline $\mathrm{SiO}_{2}$ & 75.72 & 74.85 & 45.94 \\
$\mathrm{Al}_{2} \mathrm{O}_{3}$ & 18.58 & 18.78 & 15.97 \\
$\mathrm{Fe}_{2} \mathrm{O}_{3}$ & 0.40 & 0.51 & 3.49 \\
$\mathrm{TiO}_{2}$ & 0.20 & 0.24 & 0.64 \\
$\mathrm{P}_{2} \mathrm{O}_{5}$ & $<0.01$ & 0.03 & $<0.01$ \\
$\mathrm{Na}_{2} \mathrm{O}$ & 0.73 & 1.06 & 0.72 \\
$\mathrm{~K}_{2} \mathrm{O}$ & 1.58 & 1.66 & 2.72 \\
$\mathrm{CaO}$ & 0.42 & 0.81 & 22.19 \\
$\mathrm{MgO}$ & 0.19 & 0.21 & 5.35 \\
$\mathrm{LO}$ & 1.52 & 0.91 & 2.13 \\
\hline
\end{tabular}
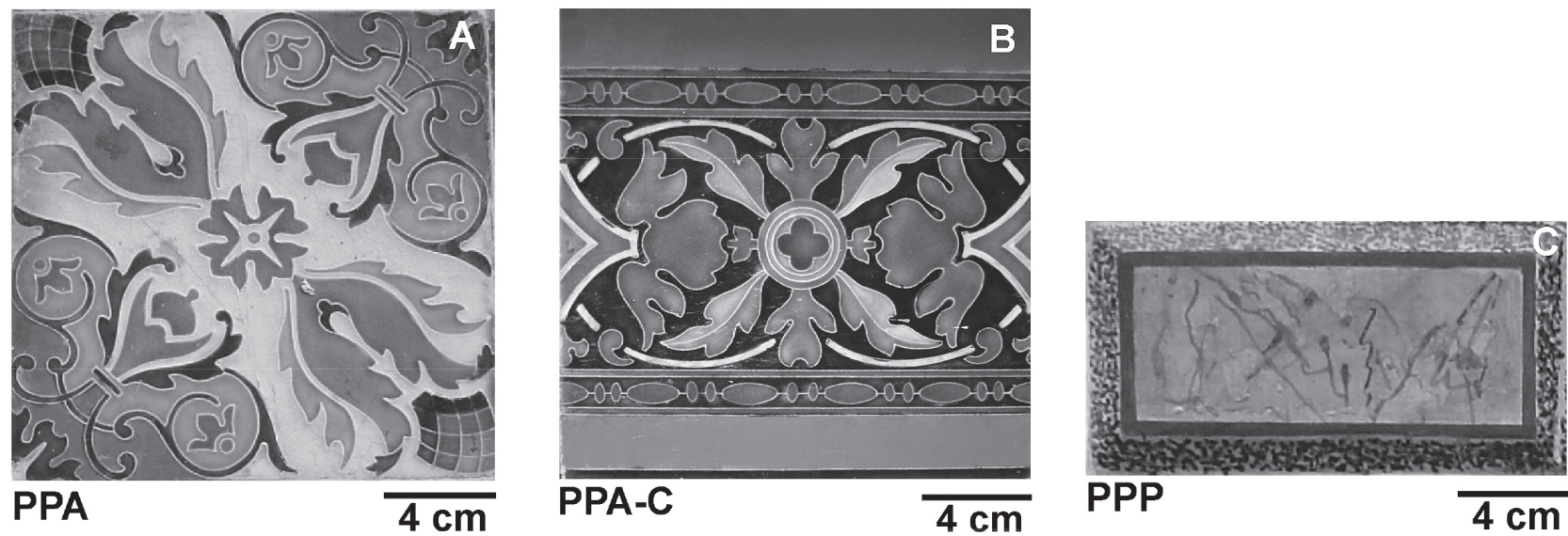

Figure 2 - German and Portuguese tiles sampled from the Pinho mansion. A: the German tile PPA; B: the German tile PPA-C; C: the Portuguese tile PPP. 
of the German tiles ( $0.4 \%$ in PPA and $0.51 \%$ in PPA-C) explains the white coloration of their ceramic portion. By contrast, the relatively high content of $\mathrm{Fe}_{2} \mathrm{O}_{3}(3.49 \%)$ in the Portuguese tile can be correlated with the lighter yellow color of its ceramic portion. The compounds $\mathrm{Na}_{2} \mathrm{O}, \mathrm{K}_{2} \mathrm{O}, \mathrm{MgO}$ and $\mathrm{P}_{2} \mathrm{O}_{5}$ are present at low concentrations (Table 1). They are commonly added during production of the glaze, in order to reduce the fusion temperature of the mixture. Normally materials such as feldspars, apatite, carbonates, marine salt, and volcanic ash are used.

The glaze of both types of tile is formed mainly by $\mathrm{SiO}_{2}$ and $\mathrm{PbO}$, which is quite distinct from the composition of the ceramics. In the German glaze, $\mathrm{CaO}$ is the third most abundant component, although in the Portuguese glaze, this is $\mathrm{K}_{2} \mathrm{O}$ (Table 2). These differences may reflect those in the composition of the respective fusion materials, which were possibly calcium carbonates and potassium feldspars, respectively. Other chemical components identified in the glaze included $\mathrm{Al}_{2} \mathrm{O}_{3}, \mathrm{Na}_{2} \mathrm{O}, \mathrm{MgO}, \mathrm{CoO}$, and $\mathrm{FeO}$. The latter two compounds - $\mathrm{CoO}$ and $\mathrm{FeO}$ - may have been added to provide coloration agents, blue and orange to yellow, respectively.

Three types of grain were identified in the glaze: $\mathrm{SiO}_{2}-$ and $\mathrm{CaPO}_{4}$-bearing grains were found in both German and Portuguese tiles, although they were more frequent in the latter. Grains bearing $\mathrm{SnO}_{2}$ were identified only in the German opaque glazes. Materials containing $\mathrm{SnO}_{2}$ have been widely recorded in tiles from the $17 \mathrm{th}, 18 \mathrm{th}$, and 19th centuries (Kock and De Waal 2008; Guilherme et al. 2011; Coentro et al. 2012), in which they were used to guarantee the opacity of the base of the decoration. In general, transparent glazes do not contain $\mathrm{SnO}_{2}$. Despite being used on a large scale in the Portuguese tile industry, $\mathrm{SnO}_{2}$ was not recorded in the present study, which indicates that the tiles were produced in the city of Porto, where $\mathrm{PbO}$ was used instead of $\mathrm{SnO}_{2}$ (Lepierre 1899). A thin layer of Sb between the ceramic body and the glaze may be the source of the orange coloration of the frame of the Portuguese tiles.

\section{Mineralogy of ceramics and glaze}

The ceramic part of the German tiles (samples PPA and PPA-C) is constituted mainly of quartz, mullite, and cristobalite. Calcite was identified only in PPA. The presence of amorphous materials is indicated by a high level of background XRD patterns. The results of the chemical SEM/ EDS analysis (Table 2), which indicated a reduced content of $\mathrm{P}_{2} \mathrm{O}_{5}$ and $\mathrm{TiO}_{2}$, reflects reduced amounts of apatite and rutile and/or anatase, respectively.

By contrast, the ceramic part of the Portuguese tiles is basically formed of quartz, gehlenite, diopside, and calcite, as well as feldspars, which is quite distinct from the German tiles. This mineralogical composition is comparable to even older tiles from historical building in Portugal (Vaz et al. 2008; Prudêncio et al. 2012). This further reinforces the contrasts in their chemical composition and their distinct raw and fusion materials. Feldspars, in particular, are commonly used to improve the fusion of ceramic mixtures (Lepierre 1899).

The glazes are generally XRD-amorphous, as expected. However, the German glaze contains some quartz and cassiterite (opaque glaze only). The SEM/EDS chemical analyses also suggest the presence of small amounts of apatite, as indicated by low levels of $\mathrm{P}_{2} \mathrm{O}_{5}$, in both opaque and

Table 2 - Mean chemical composition (after SEM/EDS analyses) of the glazes of the German and Portuguese tiles used to face the Pinho mansion.

\begin{tabular}{|c|c|c|c|c|c|c|c|c|c|}
\hline \multirow{2}{*}{ Samples } & \multicolumn{3}{|c|}{ PPA (13 points) } & \multicolumn{3}{|c|}{ PPA-C (13 points) } & \multicolumn{3}{|c|}{ PPP (12 points) } \\
\hline & Average & Min. & Max. & Average & Min. & Max. & Average & Min. & Max. \\
\hline $\mathrm{SiO}_{2}$ & 51.21 & 44.10 & 56.62 & 52.67 & 50.67 & 58.56 & 49.45 & 42.69 & 53.46 \\
\hline $\mathrm{Al}_{2} \mathrm{O}_{3}$ & 2.39 & 1.78 & 3.47 & 2.30 & 1.72 & 3.06 & 1.22 & 0.85 & 2.02 \\
\hline $\mathrm{FeO}$ & 1.65 & 0.19 & 4.48 & 7.23 & 4.15 & 9.32 & $1.46^{c}$ & $0.3^{c}$ & $2.67^{c}$ \\
\hline $\mathrm{Na}_{2} \mathrm{O}$ & 2.03 & 1.24 & 2.78 & $1.16^{a}$ & $0.87^{a}$ & $2.23^{a}$ & $1.06^{c}$ & $0.58^{c}$ & $1.37^{\circ}$ \\
\hline $\mathrm{K}_{2} \mathrm{O}$ & 3.03 & 2.08 & 4.78 & 2.57 & 2.12 & 3.72 & 9.34 & 8.41 & 11.07 \\
\hline $\mathrm{CaO}$ & 11.49 & 9.36 & 13.86 & 10.34 & 7.32 & 11.99 & $2.16^{d}$ & $1.74^{d}$ & $2.50^{\circ}$ \\
\hline $\mathrm{MgO}$ & $1.26^{a}$ & $0.44^{\mathrm{a}}$ & $2.12^{\mathrm{a}}$ & $1.22^{\mathrm{b}}$ & $0.21^{\mathrm{b}}$ & $1.88^{b}$ & $1.31^{\mathrm{b}}$ & $0.72^{b}$ & $2.83^{b}$ \\
\hline $\mathrm{CoO}$ & ND & ND & ND & $0.72^{d}$ & $0.08^{d}$ & $1.31^{\mathrm{d}}$ & ND & ND & ND \\
\hline $\mathrm{ZnO}$ & ND & ND & ND & 0.69 & 0.69 & 0.69 & 2.04 & 1.25 & 4.08 \\
\hline $\mathrm{PbO}$ & 26.50 & 22.90 & 28.49 & 22.12 & 18.29 & 24.23 & 34.77 & 29.33 & 40.08 \\
\hline
\end{tabular}

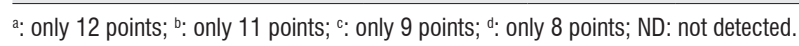


transparent glazes. On the other hand, the Portuguese glazes are predominantly amorphous, with few quartz grains and little apatite (SEM/EDS analyses).

\section{Physical characteristics}

The German tiles present 9.59\% (sample PPA-C) and $12.96 \%$ (sample PPA) total water absorption (accessible porosity), much lower than the value recorded for the Portuguese sample $-29.34 \%$. This difference may be related to the higher frequency of fissures in the ceramic portion of the Portuguese tiles. These values are very low in comparison with the value of $42 \%$ recorded for Hispanic-Moorish tiles from the 16th century, but more similar to the value of $23 \%$ for 17th-century Portuguese tiles (Santos et al. 2012). The German tiles are denser - 1.99 (PPA-C) and $1.92 \mathrm{~g} \mathrm{~cm}^{-3}$ (PPA) - than the Portuguese tile, $1.59 \mathrm{~g} \mathrm{~cm}^{-3}$. Air bubbles and large fissures are common in the glaze of the Portuguese tiles (Figueiredo 2003; Sanjad 2007; Coentro et al. 2012), which contributes to their low density. The German glaze is also thicker (0.04 to $0.2 \mathrm{~mm}$ ) than the Portuguese glaze (0.06 to $0.1 \mathrm{~mm}$ ), although their ceramic bodies are more similar, with values of $1.10-1.12 \mathrm{~cm}$ and $0.75-1.21 \mathrm{~cm}$, respectively. The glazes, in particular in the Portuguese tiles, are cross-cut by fissures and present numerous small air bubbles that formed during the firing process.

\section{The main products of degradation in the exposed tiles}

The most prominent weather-related modifications of the tiles include deposits of thin layers of organic carbon and inorganic airborne particles, and the development of dark stains between the glaze and the ceramics (German tiles). In the case of the Portuguese tiles, the modification also includes the darkening of areas that have lost their glaze and the establishment of oxidation stains (Figures 3 and 4). Another feature related to degradation or weathering is the detachment of the tile from the masonry (Figure 4), as well as the intensification and expansion of glaze fissures.

The thin layer of inorganic particles deposited over the glaze is made up of quartz, kaolinite, and calcite, or amorphous materials. Quartz and kaolinite are common components of the local subsoil and are likely derived from the immediate environment surrounding the building. Calcite is not found in this material, however, and is probably derived from the construction and restoration process, through the reaction between the calcium hydroxide in the mortar used to cement the tiles and $\mathrm{CO}_{2}$ from atmosphere, or the use of cement mortar in the past in some parts of the Pinho mansion.

Mineralogically, the dark stains observed in both types of tile are no different from the ceramic body or glaze, which indicates that this modification is due to physical changes and the early development of microorganisms. As soon as

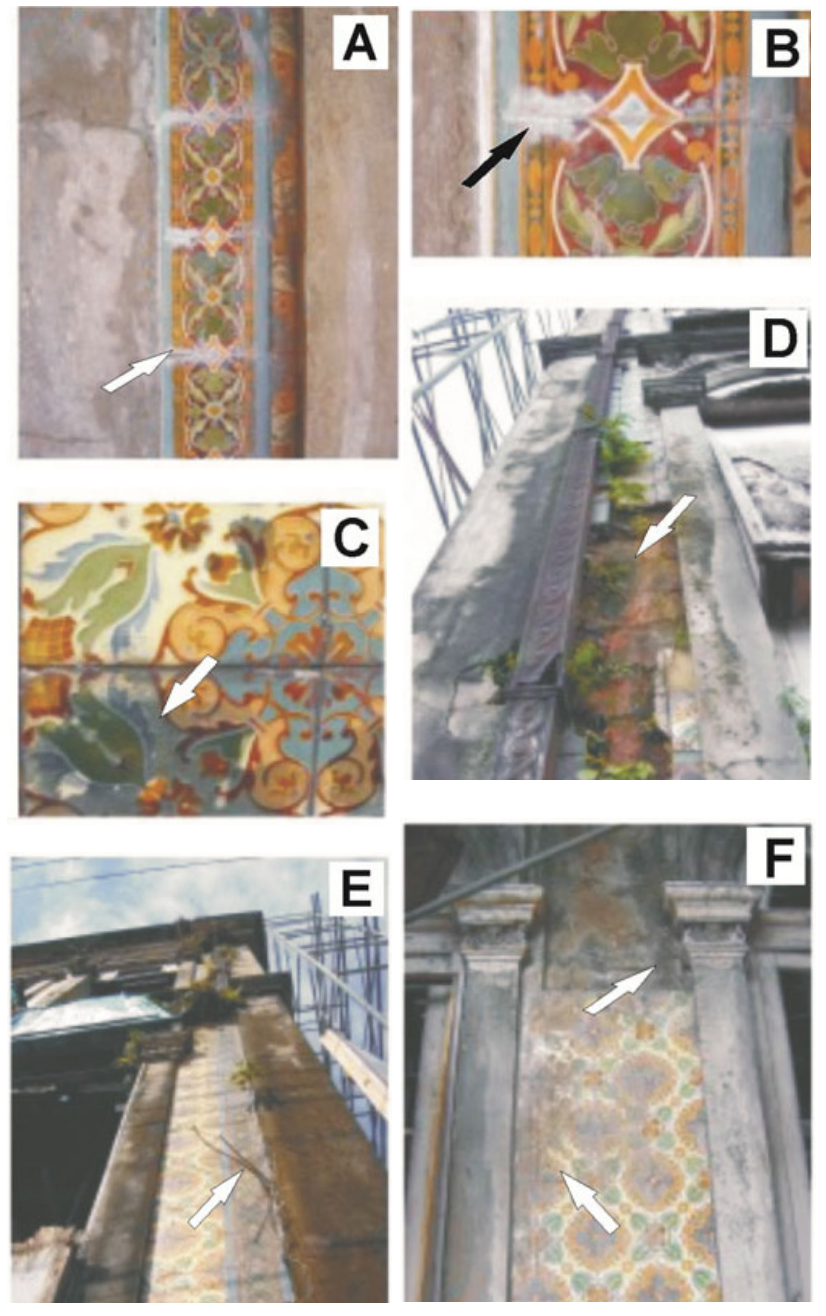

Figure 3 - The main weathering effects observed in the German and Portuguese tiles. A and B - Mortar exuding over the glaze; $\mathrm{C}$ - Dark stains under the glaze; $\mathrm{D}$ - Loss of tiles and invading vegetation; $\mathrm{E}$ - Solid airborne particles deposited close to the masonry; $\mathrm{F}$ - Mortar exuding over the glaze. All these photographs are shown in color in the electronic version.

the Portuguese tiles lose their glaze, the exposed ceramic body becomes powdery, with loose grains, and is covered by a dark crust made up of organic and inorganic material.

\section{The action of microorganisms}

Microorganisms of the Cyanophyta and Bacillariophyta divisions (Chroococcus, Cyanosarcina, Scytonema, and Navicula) (Figure 5) were found in the dark stains in both types of tile, although cyanophytes were much more common than bacyllariophytes. The development of microorganisms is the most important process contributing to the degradation of the tiles (Silvestre and Brito 2009). Dark stains formed by microorganisms are a common form of degradation found on a wide range of construction materials used in historical buildings (Warscheid and Braams 2000; Pepe et al. 

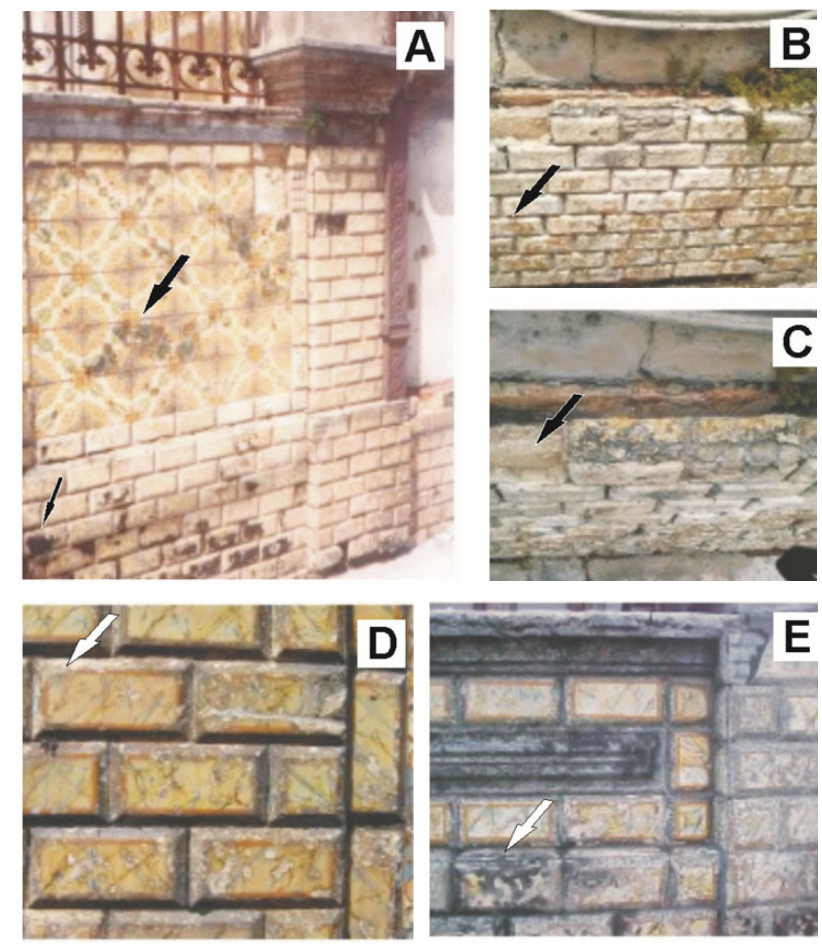

Figure 4 - The main weathering effects observed in the Portuguese tiles. A Deposition of dark stains on the ceramic body; B - Exposure of the ceramic body following removal of the dark staining; $\mathrm{C}$ - Detached tiles exposing the mortar; D - Tiles showing loss of glaze; $\mathrm{E}$ - Tiles showing some loss of glaze with dark staining on ceramic body where the glaze has been lost. All these photographs are shown in color in the electronic version.

2010; Guiamet et al. 2011). Cyanobacteria are a common component of the masonry of buildings in regions with humid tropical climates, like that of Belém (Torraca 1988; Caneva 1991; Schumann et al. 2005).
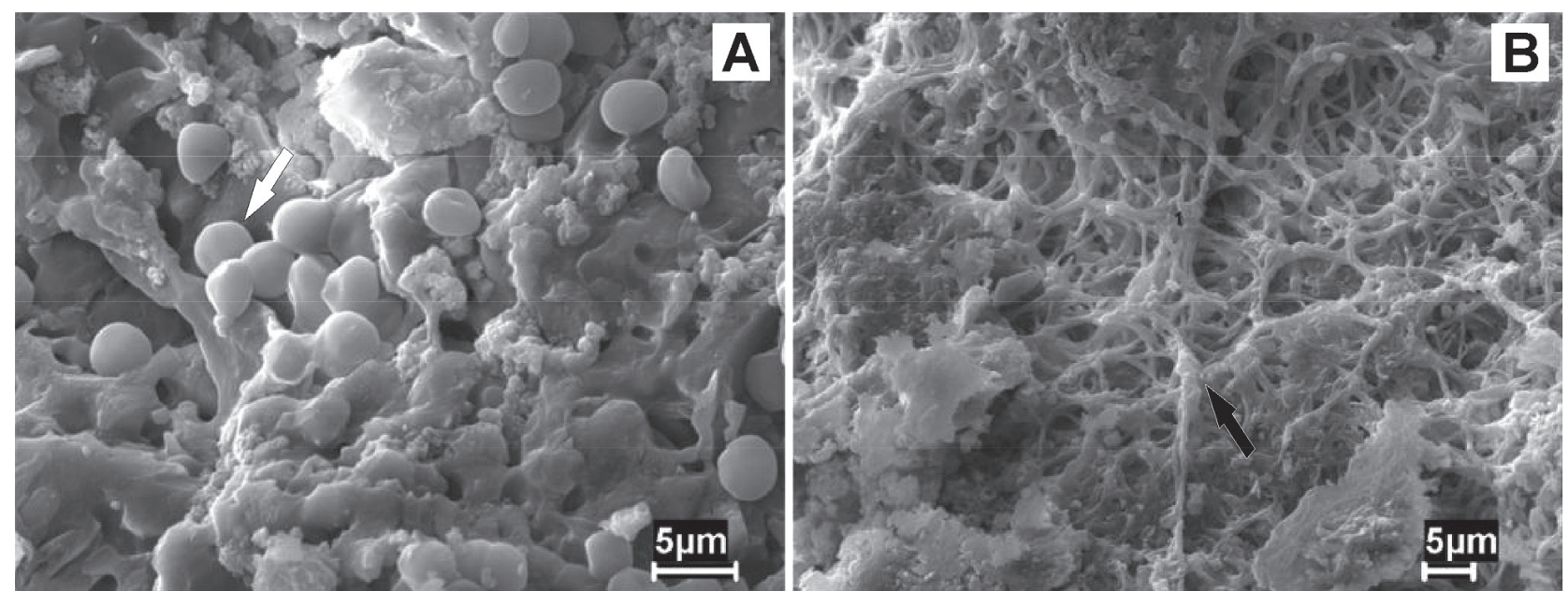

Figure 5 - SEM images of the dark stains (located between the glaze and the ceramic body) showing the different types of microorganisms. A- probably Chroococcus; B- fungal hyphae.
In addition to the staining, the microorganisms have become established at the interface between the glaze and the ceramic body of the tiles, in particular the more transparent ones, which are typical of the German style. In tiles with opaque glaze, microorganisms tend to be restricted to the fissures, given the potential for the penetration of sunlight into these features. Water and dissolved ions (nutrients), which are vital to the growth of these microorganisms, also infiltrate into these fissures. The rainwater of Belém contains many types of microorganism, including cyanobacteria and diatoms, in particular Navicula (Sanjad 2007), which are also common in the local rivers.

\section{DISCUSSION}

The distinct chemistry and mineralogy of the German and Portuguese tiles indicate they were produced from different raw materials, and probably also distinct thermal processing procedures. The ceramic portion of the German tiles is constituted of quartz, mullite, and crystobalite, rich in $\mathrm{SiO}_{2}$ and $\mathrm{Al}_{2} \mathrm{O}_{3}$, suggesting the use of a quartz-rich clay, whereas in the Portuguese tile, this portion formed by quartz, gehlenite, calcite, and diopside, as well as $\mathrm{SiO}_{2}$ and $\mathrm{Al}_{2} \mathrm{O}_{3}$, and $\mathrm{CaO}$, $\mathrm{MgO}$, and $\mathrm{Fe}_{2} \mathrm{O}_{3}$, representing either a carbonate-bearing clayey material or the addition of carbonates to the clay. The presence of mullite and crystobalite only in the German samples indicates a higher formation temperature than those used for the production of the Portuguese tiles. The formation of mullite and cristobalite from kaolinite-rich raw material requires a temperature of at least $1200{ }^{\circ} \mathrm{C}$ (Sahnoune et al. 2008), whereas gehlenite and diopside form at temperatures of around $900^{\circ} \mathrm{C}$ (Grifa et al. 2009; Prudêncio et al. 2012). The low contents of $\mathrm{Na}_{2} \mathrm{O}, \mathrm{K}_{2} \mathrm{O}, \mathrm{MgO}$ and $\mathrm{P}_{2} \mathrm{O}_{5}$ found in both German and Portuguese tiles may indicate the addition 
of materials such as feldspars, apatite, carbonates, marine salt, and volcanic ash, in order to reduce the fusion temperature of the mixture. The German and Portuguese tiles are also distinct after their glaze composition with $\mathrm{SnO}_{2}$ and $\mathrm{CaO}$ in the German ones and $\mathrm{K}_{2} \mathrm{O}$ in the Portuguese. Probably $\mathrm{Ca}$-carbonates and K-feldspars have been added, respectively, to their glaze mixtures as fusion material. These differences reflect the more advanced technology of the German factories in the 19th century. Portugal had a long tradition of ceramic production and good quality raw materials (clays and feldspars), but few of its factories were anywhere near as advanced as those of contemporary Germany, England or France (Lepierre 1899). These differences presumably contribute to their varying responses to the tropical weathering process.

In addition to the distinct chemistry and mineralogy of the German and Portuguese tiles in both the ceramic body and glazes, the glazes of Portuguese tiles are cross-cut by fissures and present numerous small air bubbles that are normally formed during the firing process. These features, together the mineralogical composition may be critical to the understanding of the susceptibility of these tiles to chemical weathering. The fissures may be responsible for the differential expansion of the glaze and the ceramics, and the detachment of the tiles from the masonry, and were probably reinforced by a century of exposure to the extremely humid local climate. Most of these kinds of tile modification have been described by Silvestre and Brito (2009) as characteristic defects of modern tiles.

The exposure of these tiles to the equatorial climate of the city of Belém, an environment quite distinct from that of the temperate latitudes in which they were produced, resulted in a disequilibrium, which has led to the major physical, mineralogical, and chemical changes identified here, in addition to the propagation of microorganisms, similar to the weathering of rocky outcrops. The most prominent effects of this process are the formation of dark stains between the glaze and ceramic body, the loss of glaze, and the propagation of a thin, darkened layer of organic and inorganic debris on the surface of the ceramic body following the loss of the glaze. However, these alterations were less accentuated in the German tiles, in comparison with those produced in Portugal, which suffered extensive loss of glaze and widespread staining. The hot and humid local climate, and the changes in the environment provoked by ongoing urban development including a drastic reduction in natural vegetation, increasing temperatures, and evapotranspiration from the paving of streets and the agglomeration of buildings, and air pollution from motorized vehicles - have certainly contributed to an acceleration of the weathering process affecting the tiles used to face the city's historic buildings. This urbanization adds gases $\left(\mathrm{CO}, \mathrm{CO}_{2}, \mathrm{H}_{2} \mathrm{O}\right)$, airborne dust (inorganic and organic dusts, which allow the formation of acidic water) and humidity, which favor the development of microorganisms, as indicated by the widespread presence of cyanobacteria and diatoms.

The presence of calcite can be related to the mortar used to fix the tiles onto the façade (Elsen 2006; Prudêncio et al. 2012) or to some uncombined $\mathrm{CaO}$ derived from the firing of the tiles (Antunes et al. 1995). The mortar used in the construction of some of Belém's historical buildings was produced with clay, sand and lime. When the tiles are applied to the façade, the water in the mortar, which contains dissolved $\mathrm{Ca}(\mathrm{OH})_{2}$, may migrate through the porous ceramic body and, once the water evaporates, the dissolved Ca may react with the $\mathrm{CO}_{2}$ in the atmosphere, leading to the precipitation of calcite (Oliveira 1995; Gadd 2007).

\section{CONCLUSION}

The distinct features and products observed in the degraded tiles of the Pinho mansion allow the identification of three distinct stages of weathering:

1) The intensification and expansion of glaze fissures;

2) The loss of glaze from the ceramic body due to processes such as thermal dilation and the action of microorganisms, especially in the case of the Portuguese tiles; and

3) Total loss of the glaze followed by the exposure of the ceramic body, which is transformed and consumed by microorganisms, and leached out by trickling rainwater. The exposed ceramic body also constitutes a highly fertile substrate for superior organisms, such as ferns, since it contains large quantities of nutrients like $\mathrm{Ca}, \mathrm{Mg}, \mathrm{K}$ and some $\mathrm{P}$, as indicated by the chemical analyses.

The relatively higher resistance of the German tiles to tropical weathering in comparison with Portuguese tiles, is related not only to their mineralogical composition (quartz and mullite, more resistant to weathering) but can be explained by their lower porosity, which impedes the infiltration of water, and thus the proliferation of microorganisms. In the German tiles, a transitional zone between the ceramics and the glaze improves the adherence of the latter, and consequently increases the resistance of the tiles to weathering, which is reinforced by the presence of weathering-resistant cassiterite, which is a main component of the opaque glaze.

\section{ACKNOWLEDGEMENTS}

We are grateful to CNPq, the Brazilian National Council for Research and Technology, for the financial support (project number 471109/03) and providing scholarships to the first and last authors. CAPES, the Brazilian Higher Education and Training Council, provided the second author with a scholarship. We also thank FUMBEL, the Belém Cultural Foundation, for permission to work at the Pinho mansion, the ESTACON construction company for support during 
fieldwork and Glayce Jholy Souza da Silva Valente for helping with manuscript preparation.

\section{REFERENCES}

Alcântara, D.M.S. 1980. Azulejos em Belém do Pará. [S.l.: s.n.]. 84 pp. Report.

Antunes, J.L., Figueiredo, M.O., Pessoa, J.C., Fortes, M.A. 1995. Characterization of Portuguese $17^{\text {th }}$ Century tiles, p. $653-660$. In: Proceedings of the International Symposium: The ceramic Heritage of the 8th CIMTEC-World Ceramics Congress and Forum of New Materials, Florence, Italy: Ed. Techna Faenza.

Caneva, G.; Nugari, M.P.; Salvatori, O. 1991. Biology in the conservation of works of art. Roma: ICCROM. $182 \mathrm{pp}$.

Coentro, S.; Mimoso, J.J.; Lima, A.M.; Silva, A.S.; Pais, A.N.; Muralha, V.S.F. 2012. Multi-analytical identification of pigments and pigment mixtures used in 17th century Portuguese azulejos. Journal of the European Ceramic Society, 32: 37-48.

Elsen, J. 2006. Microscopy of historic mortars - a review. Cement and Concrete Research, 36: 1416-1424.

Figueiredo, M.O. 2003. Estudo e caracterização de materiais cerâmicos culturais: o paradigma azulejar, p. 11-19. In: Azulejo, no 8/11, Museu Nacional do Azulejo, Lisboa.

Gadd, G.M. 2007. Geomycology: biogeochemical transformations of rocks, minerals, metals and radionuclides by fungi, bioweathering and bioremediation. Mycological Research III, 3-49.

Guiamet, P.; Borrego S.; Lavin, P.; Perdomo, I.; de Saravia, S. G. 2011. Biofouling and biodeterioration in materials stored at the Historical Archive of the Museum of La Plata, Argentine and at the National Archive of the Republic of Cuba, Colloids and Surfaces B: Biointerfaces, 85: 229-234.

Guilherme, A.; Coroado, J.; dos Santos, J.M.F.; Lühl, L.; Wolff, T.; Kanngießer, B.; Carvalho, M.L. 2011. X-ray fluorescence (conventional and 3D) and scanning electron microscopy for the investigation of Portuguese polychrome glazed ceramics: Advances in the knowledge of the manufacturing techniques. Spectrochimica Acta Part B, 66: 297-307.

Grifa, C.; Cultrone, G.; Langella, A.; Mercúrio, M.; De Bonis, A; Sebastián, E.; Morra, V. 2009. Ceramic replicas of archaeological artefacts in Benevento area (Italy): Petrophysical changes induced by different proportions of clays and temper. Applied Clay Science, 46: 231-240.

Kock, L.D.; DeWaal, D. 2008. Raman analysis of ancient pigments on a tile from the Citadel of Algiers. Spectrochimica Acta Part A: Molecular and Biomolecular Spectroscopy, 71: 1348-1354.
Lepierre, C. 1899. Estudo chimico e technologico sobre a ceramica portugueza moderna (Portuguese). Imprensa Nacional, Lisboa.

Oliveira, M.M. 1995. Tecnologia da conservaçâo e da restauração: materiais e estruturas. Salvador: Universidade Federal da Bahia, 310 pp.

Prudêncio, M.I.; Pereira, M.A.S.; Marques, J.G.; Dias, M.I.; Esteves, L.; Burbidge, C.I; Trindade, M.J.; Albuquerque, M.B. 2012. Neutron tomography for the assessment of consolidant impregnation efficiency in Portuguese glazed tiles (16th and 18th centuries). Journal of Archaeological Science, 39: 964-969.

Pepe, O.; Sannino, L.; Palomba, S.; Anastasio, M.; Blaiotta, G.; Villani, F.; Moschetti, G. 2010. Heterotrophic microorganisms in deteriorated medieval wall paintings in southern Italian churches. Microbiological Research, 165: 21-32.

Sahnoune, F.; Chegaar, M.; Saheb, N.; Goeuriot, P.; Valdivieso, F. 2008. Algerian kaolinite used for mullite formation. Applied Clay Science, 38: 304-310.

Sanjad, T.A.B.C. 2007. Intemperismo tropical em fachadas azulejadas de Belém do Pará. PhD thesis, Universidade Federal do Pará, Belém, Pará. 300 pp.

Santos, T. P.; Vaz, M. F.; Pinto, M. L.; Carvalho, A. P. 2012. Porosity characterization of old Portuguese ceramic tiles. Construction and Building Materials, 28: 104-110.

Schumann, R.; Norbert, H.; Klausch, S.; Karsten, U. 2005. Chlorophyll extraction methods for the quantification of green microalgae colonizing building facades. International Biodeterioration and Biodegradation, 55: 213-222.

Silvestre, J. D.; Brito, J. 2009. Ceramic tiling inspection system. Construction and Building Materials, 23: 653-668.

Torraca, G., 1988. Porous Building Materials: Materials Science for Architectural Conservation. Roma: ICCROM, p. 11-17.

Vaz, M.F.; Pires, J.; Carvalho A.P. 2008. Effect of the impregnation treatment with Paraloid B-72 on the properties of old Portuguese ceramic tiles. Journal of Cultural Heritage, 9: 269-276.

Warscheida, Th.; Braams, J. 2000. Biodeterioration of stone: a review. International Biodeterioration and Biodegradation, 46: 343-368.

Recebido em: 15/02/2012

Aceito em: 26/05/2012 